\title{
Legal Protection of the Rights of Workers/Laborers in Banturung Sub-District Bukit Batu Kota Palangka Raya Based on Law Number 13 of 2003 Concerning Manpower
}

\author{
Oktarianus Kurniawan ${ }^{1}$, Ronaldi $^{2}$, Rizki Setyobowo Sangalang ${ }^{3}$, Alvin Nur Aulia ${ }^{4}$ \\ 1,2,3,4Faculty of Law, Universitas Palangka Raya, Indonesia \\ Email: rizkisetyobowo@law.upr.ac.id
}

\begin{abstract}
During the covid-19 pandemic that occurred in Indonesia, which affected the economic sector, there were many layoffs by employers, except in Banturung Village, Bukit Batu District, Palangka Raya City. In Law Number 13 of 2003 concerning Manpower, it is explained about the rights and obligations of a worker in carrying out his work, in which the Act serves to protect and limit the status of the rights and obligations of workers from employers (entrepreneurs) in accordance with human dignity in the scope of work. In the conditions of the Covid-19 pandemic, both employers and workers are disadvantaged, because the weak economy makes people's purchasing power decrease and employers cannot rotate their business capital and take steps to unilaterally terminate employment relations. In Law Number 13 of 2003 concerning Employment, workers who experience termination of employment must be given severance pay.
\end{abstract}

Keywords: labor rights; workers; termination of employment; covid-19 pandemic

\section{Introduction}

Work is a relationship that involves two parties between the company and the workers/employees. The workers will get a salary as remuneration from the company / entrepreneur and the amount depends on the type of profession carried out. In the world of work, employees are required to have high work effectiveness. Organizational effectiveness is usually interpreted as the success achieved by an organization in its efforts to achieve predetermined goals. As the opinion of (Gibson, James L. 2006) saying that the effectiveness is "the achievement of goals set by cooperative effort". Clearly, if the target or goal has been achieved as it is planned before, it is called effective. Thus, if the target or goal is not completed within the allotted time, the work is not effective. The success and failure of an organization to achieve its intended goals depends on the ability of employees to carry out their duties and responsibilities for the assigned tasks to them. (Kuswati, Y. 2019)

The perpetrators of work referred to as employees, workers, laborers are basically humans who use their energy and ability to get a reward in the form of income in the form of money or other forms to the Employer or entrepreneur or employer. Basically, workers, workers, labor and employees are the same. but in Indonesian culture, "Labor" connotes a lowly worker, despicable, rude and so on. while workers, labor and employees are designations for higher-level workers, and tend to be given to workers who do not use muscles but brains in doing work. However, in essence, these four words have the same meaning, namely Worker. This mainly refers to the Manpower Law, which is generally applicable to all workers and employers in Indonesia.

In Indonesia, informal workers have increased according to the Head of the Indonesian Central Statistics Agency (BPS), Suhariyanto, the number of informal workers was 70.49 million, as of August 2019. This number is $55.72 \%$ of the total workforce in Indonesia 
when presenting the latest data to the mass media. Informal workers are those who are selfemployed, trying to be assisted by precarious workers, casual workers, and unpaid workers. As for the number of formal workers, in the same period, there were 56.02 million people. This amount is equivalent to $44.28 \%$ of the total workforce in Indonesia. "Formal workers are those who are trying to be helped by permanent workers. Also, those who become laborers, employees, and employees.

With so much increase in informal workers, the number of Micro, Small and Medium Enterprises (MSMEs) has increased. Micro, Small and Medium Enterprises in various sectors from the food, beverage, even the agricultural, plantation, livestock sectors need workers, both daily, casual and permanent workers who are given workers' rights, namely wages/salaries.

Profits from a business have an effect on conditions such as the current outbreak of the covid-19 virus, of course, it will have an impact on workers who may not be given their rights in the form of wages/salaries and even layoffs. Under any circumstances/situations the right to wages/salaries must be fulfilled which has been agreed upon by both parties, both business actors/entrepreneurs and workers, which is regulated under Law Number 13 of 2003 concerning Manpower. Business actors/entrepreneurs should continue to carry out their obligations to provide wages/salaries. The problem that occurs is that workers' rights are not given such as wages/salaries for various reasons/conditions, small harvests cause losses, so they cannot provide wages/salaries. Things like this become a dispute between workers and business actors/entrepreneurs who need evidence of a work agreement on how the wages/salaries are and the agreement of both parties. The workers are not based on a written Work Agreement, only an oral Work Agreement which is difficult to prove in the event of a dispute. With this, many workers do not know that every work should be done with a work agreement and what if there is a dispute. So the targets in carrying out this legal research are the Workers/Laborers in Banturung Village, Bukit Batu District.

Legal research will be related to legal rules related to the Protection of Workers' Rights. This is because in general, workers only know work without knowing what their rights are and knowing a job based on an existing agreement and that there is a law that regulates it in the form of workers' wage rights, examples of written work agreements so that there are no disputes. Work as well as providing information on the regulations governing workers' rights, namely Manpower Law Number 13 Year 2003.

\section{Research Methods}

The research method used in this study is an empirical legal research method, namely research in which law is not conceptualized as an autonomous normative phenomenon, but is understood as a social institution that is in real terms related to other social variables. In such a context, law as an empirical sociological phenomenon is studied on the one hand as an independent variable that causes effects on various social lives, and on the other hand as a defensive variable that appears as a resultant of various forces in the social process (study of the social process). 


\section{Result and Discussion}

\subsection{Definition of Worker/Laborer}

The term labor is very popular in the world of labor/employment, besides this term has been used for a long time even from the Dutch era as well because of the old laws and regulations (before Law No. 13 of 2003 concerning Manpower) use the term labor. In the Dutch colonial era, what he meant by labor was unskilled workers such as coolies, handymen, foremen who did menial work, these people he called "Bule Callar". Meanwhile, those who work in government or private offices are referred to as "Employees/Employees" (White Collar). The differences that brought consequences to the differences in treatment and rights by the Dutch government could not be separated from the efforts to divide the indigenous people. [7]

Law Number 13 of 2003 concerning Manpower Article 1 number 4 provides the understanding that a worker/laborer is every person who works by receiving wages or remuneration in any form. The definition is rather general but the meaning is broader because it can include all people who work for anyone, whether individuals, legal entities or other entities by receiving wages or remuneration in any form. This affirmation of compensation in any form is necessary because wages have so far been identified with money, even though there are also workers/workers who receive compensation in kind.[8]

In a labor agreement, there are several parties involved, namely laborers / workers, business / employers, trade unions / workers, employers and the government of the five elements will influence each other in carrying out its duties and functions in industrial relations. "[9]

The employment agreement consists of a work agreement for a certain period of time for a work relationship that is limited in its validity period, and an indefinite period of time for an employment relationship that is not limited to the validity period or completion of certain work. A work agreement made for a certain time is usually called a contract work agreement or a non-permanent work agreement. The status of the worker is temporary worker or contract worker. As for the work agreement made for an indefinite period of time, it is usually called a permanent employment agreement and the status of the worker is a permanent worker. A certain time work agreement is a work agreement between a worker/laborer and an entrepreneur that is only made for certain jobs which according to the type and nature or activities of the work will be completed within a certain time.[10]

\subsection{Rights of Workers/Laborers}

In Law Number 13 of 2003 concerning Manpower, it explains the rights and obligations of a worker in carrying out his work, in which the Act functions to protect and limit the status of the rights and obligations of workers from workers. Employers (entrepreneurs) in accordance with human dignity within the scope of work. The rights of workers within the scope of Law Number 13 of 2003 concerning Manpower consist of:

1. Article 5: every worker has the same opportunity without discrimination to get a job.

2. Article 6: Every worker has the right to receive equal treatment without discrimination from the employer.

3. Article 11: Every worker has the right to obtain and/or improve and/or develop work competence in accordance with his talents, interests and abilities through job training.

4. Article 12 (paragraph 3): Every worker has the same opportunity to take part in on-the-job training in accordance with his/her field of work. 
5. Article 18 (paragraph 1): Workers have the right to obtain recognition of work competence after participating in job training organized by government job training institutions, private job training institutions or on-the-job training.

6. Article 27: Workers who have participated in the apprenticeship program are entitled to recognition of work competency qualifications from companies or certification bodies.

7. Article 31: Every worker has the same rights and opportunities to choose, get or change jobs and earn a decent income at home or abroad.

Legal protection for workers is the fulfillment of basic rights inherent and protected by the constitution as regulated in Article 27 paragraph (2) of the Constitution of the Republic of Indonesia. Protection of workers is intended to guarantee workers' rights and ensure equal opportunity and treatment without discrimination on anything to realize the welfare of workers and their families while taking into account the development of the progress of the business world and the interests of entrepreneurs. Legislation related to the protection of workers, namely Law No. 13 of 2003 concerning Manpower and implementing regulations of legislation in the field of manpower.

\subsection{Forms of Legal Protection Legal}

Protection has the meaning as protection by using legal means or protection provided by law, shown to certain interests, namely by making interests also called subjective law. Subjective law is an active aspect of the legal relationship provided by objective law, in terms of subjective law are norms, rules. Legal protection is always related to the role and function of law as a regulator and protection of the public interest. Bronislaw Malinowski in his book "Crime and Custom In Savage" plays a role in situations that are full of violence and conflict, but that the law also plays a role in daily activities.[11]

Legal protection for workers is very necessary considering the position of workers is on the weak side. Protection of workers is intended to ensure the fulfillment of the basic rights of workers and guarantee equal opportunity and treatment without discrimination on any basis to realize the welfare of workers. Theoretically, in Pancasila Industrial Labor relations, there is a legal principle which states that workers and employers have equal positions. According to labor terms, they are called work partners. However, in practice, the position of the two is not equal. Entrepreneurs as owners of capital have a higher position than workers. This is clearly seen in the creation of various company regulations and regulations. Given the position of workers who are lower than their employers, it is necessary to intervene by the government to provide legal protection, so that justice in employment can be achieved more quickly.

Kranenburg is an adherent of the theory of the welfare state. According to him, the aim of the state is not only to maintain law and order, but also to be active in seeking the welfare of its citizens. Welfare in this case covers various fields, so that the goals of the State should be called plural, namely efforts to achieve the goals of the State are based on equitable and balanced justice. [12]

\subsection{Issues - Issues in Workers / Labor}

Labor relations will be able to improve a conducive business and investment climate that is favorable where in the end it really matters against the wheels economic relations between workers and employers or financier as long as entrepreneur or more indicates an antagonistic relationship than a harmonious relationship. The ideals of realizing industrial relations or also harmonious and prosperous labor relations as always mandated in various 
labor laws have never been realized. That is the real problem, so that harmonious relations have never materialized.

Some of the main problems that trigger the strengthening of antagonism in labor relations are as follows: [13]

1. The issue of freedom of association, studying labor issues cannot be separated from the existence of trade unions and strikes, both of which are the rights of every worker protected by law. Its existence has also been recognized by Law no. 21 of 2000 concerning Trade Unions or Labor Unions. To deal with possible unfair actions from employers, workers join trade unions to fight for their aspirations. Trade unions will represent and fight for the rights of workers who join, or who do not join the union. This is called collective bargaining. The ratio of collective to individual aspirations is that the position of workers will be stronger if they collectively negotiate with employers, rather than individually.

2. The adequacy of wages is a problem that also triggers the antagonistic relationship between workers and employers. The issue of wages is usually a matter of negotiation between labor unions or trade unions. Wages, even though there is a law that regulates them, are still a trigger. After all, to achieve a large operating margin, a business must reduce the company's operating costs as much as possible. One of the components is labor wages. Law No. 13 of 2003 states, every worker or laborer has the right to earn an income that meets a decent living for humanity (Article 88, paragraph 1). This means that normative workers have the right to a decent living and meet the minimum standards of labor needs. In practice, due to workers who are considered not to understand legal matters, violations of these wage rules often occur. Moreover, the bargaining power of workers is getting lower in the midst of the economic crisis and the COVID-19 pandemic. Not infrequently fellow workers split up due to inconsistency in the face of wage demands. The difference in the interpretation of the minimum wage between workers and employers is a problem that causes labor relations to become increasingly disharmonious.

3. Termination of Employment (PHK), is the thing that is most feared by workers or workers. Law No. 13 of 2003, which is also opposed by many trade unions, has paved the way for easy layoffs of workers. This convenience occurs due to the abolition of the requirement for employers to request permission to perform layoffs from the Regional and Central Labor Dispute Settlement Committees (P4) which are under the Ministry of Manpower, as previously regulated in Law no. 22 of 1957 concerning the Settlement of Labor Disputes. Article 10 states that layoffs carried out without obtaining a permit are null and void. The new law has transferred the labor settlement mechanism from the Regional or Central P4 to an institution called the Industrial Court which will become a special room in the District Court. The process of resolving labor disputes will then become the subject of legal procedures in civil law. Article 151 paragraph 3 of Law no. 13 of 2003 states that it is true that there is no agreement, the entrepreneur can only terminate the employment relationship with the worker or laborer after obtaining a determination from the industrial relations dispute settlement institution.

\subsection{Legal Protection of Workers/Laborers' Rights during the Pandemic Covid-19 Based on Law Number 13 of 2003}

Legal protection has the meaning as protection by using legal means of protection provided by law, shown to certain interests, namely by how to make the interests that need to be protected into a legal right. The law of "rights" is also called subjective law. Subjective law is an active aspect of the legal relationship provided by objective law, in terms of subjective law are norms, rules.[14] 
According to Satjipto Rahardjo, legal protection is to provide protection for human rights that are harmed by others and that protection is given to the community so that they can enjoy all the rights granted by law.[15] Meanwhile, according to CST Kansil, legal protection is a variety of legal remedies that must be provided by law enforcement officers to provide a sense of security, both mentally and physically from interference and various threats from any party.[16]

Legal protection is a universal concept of the rule of law. Basically, legal protection consists of two forms, namely preventive legal protection and repressive legal protection, namely: Preventive legal protection which basically means prevention. Preventive legal protection is very meaningful for government actions based on freedom of action because with the existence of preventive legal protection the government is encouraged to be careful in making decisions. The form of preventive legal protection is contained in the legislation in order to prevent a violation from occurring and to provide limitations in carrying out obligations. Repressive Legal Protection serves to resolve disputes that have arisen due to violations. This protection is the final protection in the form of sanctions for violations that have been committed.

Labor law protection aims to ensure the continuity of a good working relationship system without any pressure from the strong party to the weak party. In Law Number 13 of 2003 concerning Manpower, it is explained that what is called a worker/labor is anyone who works by receiving wages or other forms of remuneration. Meanwhile, according to the Big Indonesian Dictionary, a worker is a person who works for other people and gets paid. It can be concluded that a person can be said to be a worker if the person has a working relationship with the employer and gets a wage. In the relationship between the worker and the employer, it is carried out with a work agreement which in Law Number 13 of 2003 Article 1 Number 14 which reads that the work agreement is an agreement between the worker/laborer and the entrepreneur or employer that contains the terms of employment, rights and obligations of the workers.

Article 51 paragraph (1) states that a work agreement can be made in writing or verbally, paragraph (2) a written work agreement is carried out in accordance with applicable laws and regulations and in Article 52 paragraph (1) a work agreement is made on the basis of:

1. Both side agreement;

2. Ability or ability to perform legal actions;

3. The existence of the promised work; and

4. The agreed work does not conflict with public order, decency, and applicable laws and regulations.

In the explanation above, it can be concluded that the agreement made orally is also recognized by law. The rights of workers/workers based on Law Number 13 of 2003 are:

1. Equal opportunity and treatment;

2. Work training;

3. Placement of workers;

4. Protection, Wages, and Welfare, and;

5. Industrial relations.

Equal opportunity and treatment is described in Article 5 Every worker has the same opportunity without discrimination to get a job. Article 6 every worker/labor has the right to receive equal treatment without discrimination from employers. 
Job training is described in Article 11 Every worker has the right to obtain and/or improve and/or develop work competencies in accordance with their talents, interests, and abilities through job training. Article 12 paragraph (3) every worker/ laborer has the same opportunity to participate in job training in accordance with his/her field of duty. Article 18 paragraph (1) Workers have the right to obtain recognition of work competence after participating in job training organized by government job training institutions, private job training institutions, or training in the workplace. And Article 23 Workers who have participated in the apprenticeship program are entitled to recognition of work competence qualifications from companies or certification bodies.

The placement of workers is explained in Article 31. Every worker has the same rights and opportunities to choose, get, or change jobs and earn a decent income at home or abroad. Protection, Wages, and Welfare are described in Article 67 paragraph (1) Employers who employ workers with disabilities are obligated to provide protection according to the type and degree of disability. Article 78 paragraph (2) Entrepreneurs who employ workers/laborers to exceed the working time as referred to in Article 78 paragraph (1) are required to pay overtime wages. Article 79 paragraph (1) Employers are obliged to give rest and leave time to workers/ laborers. Article 80 Employers are obliged to provide adequate opportunities for workers/laborers to carry out the worship required by their religion. Article 82 paragraph (1) Female workers/laborers are entitled to a break for 1.5 (one and a half) months before giving birth to a child and 1.5 (one and a half) months after giving birth according to the calculation of the obstetrician or midwife, paragraph (2) Workers/ female workers who experience miscarriages are entitled to 1.5 (one and a half) month's rest or in accordance with a certificate from an obstetrician or midwife. Article 84 every worker/laborer who uses the right to rest time as referred to in Article 79 paragraph (2) letters b, c, and d, Article 80, and Article 82 is entitled to full wages. Article 85 paragraph (1) Workers/laborers are not obliged to work on official holidays. Article 86 paragraph (1) every worker/labor has the right to obtain protection for:

- Occupational Health and Safety;

- Morals and decency; and

- Treatment in accordance with human dignity and values and religious values.

Article 88 paragraph (1) every worker/labor has the right to earn an income that fulfills a decent living for humanity. Article 90 paragraph (1) Employers are prohibited from paying wages lower than the minimum wage as referred to in Article 89. Article 99 paragraph (1) every worker/labor and their family has the right to obtain labor social security. Article 104 paragraph (1) every worker/ laborer has the right to form and become a member of a trade union/ labor union.

From the results of interviews with the Banturung Village Head, Bukit Batu District, Palangka Raya City, Bambang, S. Sos, the MAP of termination of employment that was carried out unilaterally by the employer during the Covid-19 pandemic totaled 15 cases.[17] From the results of the interview, it was also known that the worker who was terminated made a verbal work agreement [18] which is included in the Work Agreement for an Indefinite Time (PKWTT). In an Indefinite Work Agreement (PKWTT), workers who are terminated must receive severance pay. 


\subsection{Factors Causing Layoffs of Workers/Laborers in Banturung Village, Bukit Batu District, Palangka Raya City}

The business group that terminates employment in the Banturung Complaint, Bukit Batu District, Palangka Raya City is included in the micro-enterprise. The criteria for microenterprises according to Law Number 20 of 2008 Article 6 paragraph (1) are to have a net worth of a maximum of Rp. 50,000,000.00 (fifty million rupiahs) excluding land and buildings for business premises, and to have annual sales of a maximum of $\mathrm{Rp} 300.000 .000,00$ (three hundred million rupiah).

Micro business itself is included in a business carried out by the lower middle class community in starting their business with very small capital. [19] The characteristics of microenterprises are as follows:

1. Capital of not more than 10 million capital issued by micro-enterprises usually does not exceed 10 million.

2. Workforce No More Than 10 Workers. Micro-enterprises usually have no more than 10 workers or employees, this is based on the small scope of business and is influenced by the strength of the entrepreneur's capital in employing their employees. In general, microentrepreneurs will be directly involved in managing their business so that they rarely need other employees to oversee the running of their business.

3. Using Family Members as Employees or Work Partners. In developing their business, micro-enterprises tend to use relatives or family they know as employees. And micro business entrepreneurs usually increase their business by collaborating with their families such as working together in stocking raw materials, renting other family-owned shops. In addition to using relatives or family as workers, micro entrepreneurs carry out business management independently.

4. Small-scale businesses, another characteristic of micro-enterprises is that the businesses they run are classified as small-scale. Starting from production activities and goods sold are still classified in small quantities. In running their business, micro entrepreneurs usually use their self-taught experience.

5. Micro business entrepreneurs generally use natural resources or other traditional equipment in running their business.[20]

According to Rukitah and Darda Sahrizal, not all companies can apply in terms of providing wages to their workers in accordance with statutory regulations, especially small companies so in this case the government should be able to pay more attention to workers/ laborers better so that workers/ laborers can receive even better wages.[21]

From the results of interviews with business actors, it was found that the causes of layoffs for workers/laborers in Banturung Village, Bukit Batu District, Palangka Raya City were influenced by 2 factors, namely internal factors and external factors, both of which were interconnected.

\section{Internal factors}

Internal factors are factors that come from the business actors themselves, from the results of interviews conducted with business actors that cause layoffs due to the ineffective behavior of the cultivation/livestock, plantation and other products they manage which causes the inability of business actors to turn over their business capital.

2. External Factors

External factors are factors that come from outside of business actors, from the results of interviews with business actors that cause layoffs due to weak economic conditions due to the Covid-19 pandemic. 
External factors are the most influential factors in the occurrence of unpaid job terminations, where as a result of the Covid-19 pandemic which makes the economy weak, business actors (micro) are unable to rotate business capital, plus business groups classified as micro with small business capital. Law Number 13 of 2003 concerning Manpower mandates that if a worker has an Indefinite Work Agreement (PKW'T') in the event of termination of employment, the employer is obliged to provide payment.

\section{Conclusion}

In Law Number 13 of 2003 Article 51 paragraph (1) states that a work agreement can be made in writing or verbally. The rights of workers/workers based on Law Number 13 of 2003 are: equal opportunity and treatment, job training, placement of workers, protection, wages/welfare, and industrial relations. From the results of interviews, workers who experienced termination of employment made a verbal work agreement which was included in the Indefinite Time Work Agreement (PKWT'T). In an Indefinite Work Agreement (PKWTT), workers who are terminated must receive severance pay. The causes of layoffs for workers / laborers in the Banturung Village, Bukit Batu District, Palangka Raya City are influenced by 2 factors, namely internal factors and external factors which are both interconnected, internal factors are factors that come from the business actors themselves, from the results of interviews conducted with the perpetrators. The causes of layoffs are due to the ineffectiveness of the results of cultivation/livestock, plantations and others that they manage which causes the inability of business actors to rotate their business capital, external factors are factors that come from outside the business actor, from the results of interviews with business actors the cause of layoffs is weak economic conditions due to the Covid-19 pandemic.

\section{References}

Abdul Khakim. (2007). Hukum Ketenagakerjaan Indonesia, P'T. Citra Aditia Bakti, Bandung. Joni Bambang, 2013. Hukum Ketenagakerjaan, Pustaka Setia, Bandung

CST Kansil. (1989). Pengantar Ilmu Hukum dan Tata Hukum Indonesia, Balai Pustaka, Jakarta, hlm.102.

Dosen Fakultas Hukum Universitas Palangka Raya.

Dosen Fakultas Hukum Universitas Palangka Raya.

Dosen Fakultas Hukum Universitas Palangka Raya.

Hasil Wawancara dengan Lurah Banturung Kecamatan Bukit Batu, Kota Palangka Raya, Bambang, S. Sos, MAP

Heru Suyanto. (2012). Kontroversi Buruh dan Pengusaha, Jakarta; HS Publishing.

Heru Suyanto, Kontroversi Buruh dan Pengusaha, Jakarta; HS Publishing. (2012). hlm. 32.

Heru Suyanto, Andriyanto Adhi Nugroho, Perlindungan Hukum Terhadap Hak-Hak Pekerja

Outsourcing Berdasarkan Asas Keadilan, Fakultas Hukum Universitas Pembangunan

Nasional "Veteran” Jakarta, Hlm. 5.

https://www.topbusiness.id, jumlah pekerja informal 7049-juta-orang, diakses pada tanggal 08

Oktober 2020.

https://www.topbusiness.id, jumlah pekerja informal 7049-juta-orang.

https://dosenekonomi.com/ilmu-ekonomi/ekonomi-mikro/ciri-ciri-usaha-mikro.

Joni Bambang, Hukum Ketenagakerjaan, Pustaka seti, Bandung, 2013, hlm. 73.

Kuswati, Y. (2019). Motivation Role in Improving Work Effectiveness. Budapest International

Research and Critics Institute-Journal (BIRCI-Journal). P. 281-288

Lalu Husni. (2008). Pengantar Hukum Ketenagakerjaan Indonesia, Jakarta: Raja Grafindo. 
Lalu Husni. (2008). Pengantar Hukum Ketenagakerjaan Indonesia, Raja Grafindo, Jakarta, hlm. 33.

Mahasiswa Fakultas Hukum Universitas Palangka Raya.

Rukitah \& Darda Sahrizal. (2013). Undang-Undang Ketenagakerjaan \& Aplikasinya, Dunia Cerdas. Jakarta, hlm. 207.

Sehat Damanik. (2006). Outsourcing dan Perjanjian Menurut Undang-Undang Nomor 13 Tahun 2003 tentang Ketenagakerjaan. Jakarta; DSS Publishing, hlm. 102.

Soeroso, Pengantar Ilmu Hukum, Sinar Grafika,Jakarta, 2006, hlm. 16.

Stephen Dakin and J. Scott Armstrong . Predicting job performance: A comparison of expert opinion and research findings". International Journal of Forecasting. 5, hlm. 187-194.

Satjipto Rahardjo. (2000). Ilmu Hukum, PT. Citra Aditya Bakti, Bandung, hlm. 54. 